\title{
EFFECT OF FOLLICULAR FLUID ON MOTILITY OF THAWED BOAR SPERMATOZOA
}

\section{J. KOZUMPLIK}

\author{
Department of Farm Animal Reproduction and Surgery, University of Veterinary Science, \\ 61242 Brno
}

Received October 27, 1977

\begin{abstract}
Kozumplik J.: Effect of Follicular Fluid on Motility of thawed Boar Spermatozoa. Acta vet. Brno 47, 1978: 33-38.

Boar spermatozoa in volumes of $0.1 \mathrm{ml}, 2 \mathrm{ml}$ and $5 \mathrm{ml}$ were pellet-frozen on solid carbon dioxide, and, in volumes of $2 \mathrm{ml}, 5 \mathrm{ml}$ and $10 \mathrm{ml}$ were frozen in form of cylinders in evaporation of liquid nitrogen. After 1-6 months of storage, follicular fluid from sow ovaria was added to a part of thawed ejaculates, and, motility of spermatozoa kept at $38.5^{\circ} \mathrm{C}$ was evaluated. Motility of spermatozoa frozen in $10 \mathrm{ml}$ was significantly lower than that of spermatozoa frozen in $0.1 \mathrm{ml}$ volume. About $30 \%$ of thawed spermatozoa showed straight movement. After 6 hours, their motility decreased to $7 \%$ in average $(2-10 \%)$, and to $12 \%(9-15 \%)$ if follicular fluid has been added. In non-frozen ejaculates kept under identical conditions, $48 \%$ of spermatozoa showed motility. Following insemination with frozen-thawed spermatozoa, 7 gilts from 16 fell pregnant $(43.75 \%)$. The comparatively low survival of thawed spermatozoa might be an explanation for low fertility rate in inseminated sows.
\end{abstract}

Boars, deep-freezing of spermatozoa, volume, survival of spermatozoa, fertility rate.

Hammer and Williams (1964), Foley and Williams (1967), Grotjan et al. (1974) and others demonstrated recently that follicular fluid as well as secretion from oviducts supported motility and respiration of spermatozoa. Simultaneously it has been pointed out that follicular fluid from one species agglutinates spermatozoa of another species. If, nevertheless, for example bovine follicular fluid has been heated, the toxic factor was destroyed, and, elevated respiration and motility could be observed even after additon of boar spermatozoa (Yanagimachi 1969; Grotjan et al. 1975).

The effect of follicular fluid has not yet been studied with frozen-thawed spermatozoa. Since their vitality after thawing is limited, we tried to prolong metility of boar spermatozoa by addition of follicular fluid from ovaria and endometrial secretion from sows slaughtered during the follicular phase of sexual cycle.

\section{Materials and Methods}

The second fraction of ejaculate from 4 Landrace boars obtained by manual method was used for freezing of spermatozoa. The ejaculates were kept at room temperature for 1 hour and then diluted $1: 1$ by one of the two tested solutions described in Table 1. The diluted ejaculates were poured into special jars with ground neck and an outlet through the stopper. Air was removed from the jars by a vacuum pump and replaced by hydrogen. After keeping it in hydrogen atmosphere at $+5{ }^{\circ} \mathrm{C}$ for 3 hours, the diluted ejaculates were placed for 20 minutes in a water bath containing lumps of ice (Konovov 1975). Then, volumes of $0.1 \mathrm{ml}, 2 \mathrm{ml}$ and $5 \mathrm{ml}$ were exposed to freezing to pellets on solid carbon dioxide, or volumes of $2 \mathrm{ml}, 5 \mathrm{ml}$ and $10 \mathrm{ml}$ to cylinders formed from aluminium foil in evaporation of liquid nitrogen. Frozen spermatozoa were kept in liquid nitrogen for 1-6 months. 
Table 1

Composition of diluents

\begin{tabular}{|c|c|c|}
\hline & Diluent No. 1 & Diluent No. 3 \\
\hline $\begin{array}{l}\text { Sucrose } \\
\text { Glucose } \\
\text { Fructose } \\
\text { ADTA } \\
\text { TRIS } \\
\text { Calcium monoxide } \\
\text { Magnesium oxide } \\
\text { Citric acid } \\
\text { Sodium citrate } \\
\text { Glycerol } \\
\text { Yolk } \\
\text { Distilled water } \\
\text { ad }\end{array}$ & $\begin{array}{c}60.0 \mathrm{~g} \\
6.0 \mathrm{~g} \\
\overline{-} \\
12.0 \mathrm{~g} \\
-\overline{0} \\
0.4 \mathrm{~g} \\
0 . \overline{\mathrm{g}} \\
2.0 \mathrm{~g} \\
40.0 \mathrm{ml} \\
50.0 \mathrm{ml} \\
1,000.0 \mathrm{ml}\end{array}$ & $\begin{array}{c}60.0 \mathrm{~g} \\
-\overline{6.0 \mathrm{~g}} \\
4.0 \mathrm{~g} \\
4.0 \mathrm{~g} \\
- \\
\overline{2.5} \mathrm{~g} \\
\overline{-} \\
40.0 \mathrm{ml} \\
50.0 \mathrm{ml} \\
1,000.0 \mathrm{ml}\end{array}$ \\
\hline
\end{tabular}

Table 2

Motility of spermatozoa after thawing

\begin{tabular}{|c|c|c|c|c|c|c|c|c|c|c|c|c|}
\hline \multirow[b]{2}{*}{$\begin{array}{l}\text { Vol- } \\
\text { ume } \\
\text { in } \mathrm{ml}\end{array}$} & \multicolumn{6}{|c|}{ Diluent No. 1} & \multicolumn{6}{|c|}{ Diluent No. 3} \\
\hline & 0.1 & 2.0 & 5.0 & $2.0^{+}$ & $5.0^{+}$ & $10.0^{+}$ & 0.1 & 2.0 & 5.0 & $2.0^{+}$ & $5.0^{+}$ & $10.0^{+}$ \\
\hline $\begin{array}{l}\% \text { of } \\
\text { mo- } \\
\text { ving } \\
\text { sper- } \\
\text { mato- } \\
\text { zoa }\end{array}$ & $\begin{array}{c}36 \\
\pm \quad 6.75\end{array}$ & $\begin{array}{c}35 \\
\pm 7.63\end{array}$ & $\begin{array}{c}29 \\
\pm \quad 7.74\end{array}$ & $\begin{array}{c}35 \\
\pm 7.63\end{array}$ & $\begin{array}{c}30 \\
\pm 5.45\end{array}$ & $\begin{array}{c}19 \\
\pm \quad 7.12\end{array}$ & $\begin{array}{c}34 \\
\pm 6.66\end{array}$ & $\begin{array}{c}30 \\
\pm 5.24\end{array}$ & $\begin{array}{c}29 \\
\pm \quad 6.87\end{array}$ & $\begin{array}{c}34 \\
\pm 6.41\end{array}$ & $\begin{array}{c}30 \\
\pm 7.50\end{array}$ & $\begin{array}{c}19 \\
\pm \quad 8.10\end{array}$ \\
\hline
\end{tabular}

+ Frozen in evaporation of liquid nitrogen

Pellets were thawed on a teflon pan at $42{ }^{\circ} \mathrm{C}$. One part of follicular fluid was added to 2 parts of thawed spermatozoa, and, the test tubes containing samples were placed in a water bath at $38.5^{\circ} \mathrm{C}\left( \pm 0.5^{\circ} \mathrm{C}\right)$.

Follicular fluid from ovaria or endometrial secretion from sows killed in the course of follicular phase of sexual cycle was centrifuged, the supernatant drawn off, frozen and stored at $-20^{\circ} \mathrm{C}$. Survival of spermatozoa was microscopically examined in the course of 6 hours, and, spermatozoa with progressive motion only were considered alive. This way of examination was applied for each volume and form of frozen ejaculate under study.

\section{Results}

Solution No. 1 (Tab. 2) seemed to have the best composition, though the difference between both solutions tested was not statistically significant. Evaluation of the effect of various volumes used for freezing made it obvious that there was no difference in motility of spermatozoa as far as volumes $0.1 \mathrm{ml}, 2.0 \mathrm{ml}$ and $5.0 \mathrm{ml}$ were concerned. The motility of spermatozoa frozen in $0.1 \mathrm{ml}$ was significantly higher than in $10 \mathrm{ml}$. Results concerning motility are summarized in Table 2, their statistical evaluation im Tab. 3. There was virtually no difference between volumes $0.1 \mathrm{ml}$ and $2 \mathrm{ml}$, while in $5 \mathrm{ml}$ the motility of spermatozoa was decreased, although not to a significant degree. Practical implications concern not only the 
period of time requested for freezing the insemination dose, but, the whole processing of large amounts of spermatozoa.

Disregarding the volume frozen, thawed spermatozoa survived a considerably shorter period of time than spermatozoa in freshly diluted ejaculate. After 6 hours in a water bath at $38.5^{\circ} \mathrm{C}$, not more than $10 \%$ of thawed spermatozoa showed

Fig. 1.

Motility of spermatozoa in the course of

6 hours in water bath at $38.5^{\circ} \mathrm{C}$.

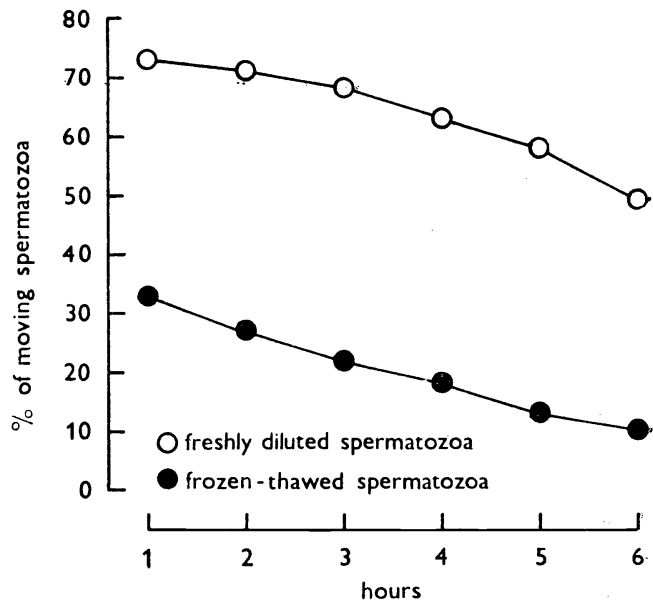

progressive movement, while an average of $48 \%$ was registered with freshly diluted spermatozoa (Fig. 1).

The effect of follicular fluid on the rate of moving spermatozoa was studied under the same conditions. Follicular fluid influenced both the number and the duration of motility. With progress of time, comparatively more motile spermatozoa were present in samples with follicular fluid so that they differed by $3-6 \%$ from control samples at final evaluation. The results are in agreement with the findings described by Foley et al. (1967), Grotjan et al. (1974), and others.

Table 3

Statistical evaluation of effect of frozen-thawed volume on motility of spermatozoa

\begin{tabular}{|c|c|c|c|c|}
\hline $\begin{array}{l}\text { Volume of } \\
\text { spermatozoa }\end{array}$ & $\begin{array}{r}\text { Criteria } \\
\text { compared }\end{array}$ & Critical values & Significance & $n$ \\
\hline $\begin{array}{l}\text { Diluent } \\
\text { No. } 1\end{array}$ & $\begin{array}{l}0.1 \mathrm{ml}: 2 \mathrm{ml} \\
0.1 \mathrm{ml}: 5 \mathrm{ml} \\
0.1 \mathrm{ml}: 2 \mathrm{ml}^{+} \\
0.1 \mathrm{ml}: 5 \mathrm{ml}^{+} \\
0.1 \mathrm{ml}: 10 \mathrm{ml}\end{array}$ & $\begin{array}{l}0.5064 \\
1.1503 \\
0.4249 \\
1.3684 \\
5.7518\end{array}$ & $\begin{array}{l}0 \\
0 \\
0 \\
0 \\
P=0.01++\end{array}$ & $\begin{array}{l}11 \\
11 \\
11 \\
11 \\
11\end{array}$ \\
\hline $\begin{array}{l}\text { Diluent } \\
\text { No. } 3\end{array}$ & $\begin{array}{l}0.1 \mathrm{ml}: 2 \mathrm{ml} \\
0.1 \mathrm{ml}: 5 \mathrm{ml}^{+} \\
0.1 \mathrm{ml}: 2 \mathrm{ml}^{+} \\
0.1 \mathrm{ml}: 5 \mathrm{ml}^{+} \\
0.1 \mathrm{ml}: 10 \mathrm{ml}\end{array}$ & $\begin{array}{c}1.0122 \\
1.1650 \\
0 \\
1.6265 \\
6.6769\end{array}$ & $\begin{array}{l}0 \\
0 \\
0 \\
0 \\
=0.01++\end{array}$ & $\begin{array}{l}11 \\
11 \\
11 \\
11 \\
11\end{array}$ \\
\hline
\end{tabular}

+ Frozen in evaporation of liquid nitrogen Advantage for $0.1 \mathrm{ml}$ 

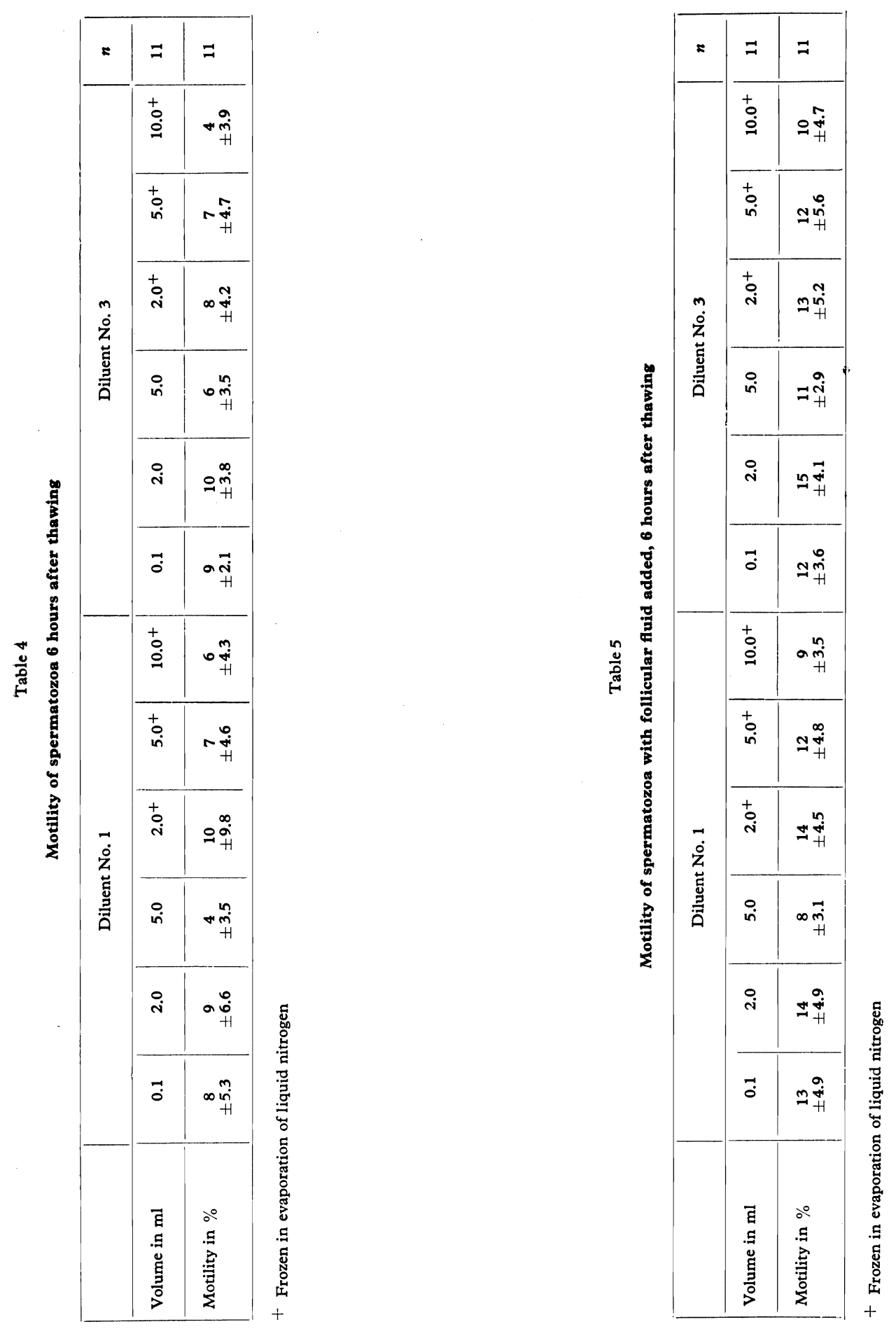
A favourable effect could be generally observed in every sample with follicular fluid (Tab. 4 and 5). The difference in motility of spermatozoa was of statistical significance in $66.6 \%$ of volume categories. The real difference in motility, ranging from $1 \%$ to $13 \%$ after 6 hours in water bath at $38.5^{\circ} \mathrm{C}$, does not appear to be ample. Understandably, follicular fluid can act only upon spermatozoa not damaged by freezing to an extent which would influence their metabolic processes. Table 6 shows that follicular fluid was less efficient with the diluent No. 1. More examination will be needed to elucidate this fact, since without addition of follicular fluid, diluent No. 1 appeared to be slightly superior to diluent No. 3 .

Conclusively it is to be stated that boar spermatozoa frozen and thawed in the described way can survive a comparatively short period of time only. An average of $7 \%(4-10)$ spermatozoa survived 6 hours at $38.5^{\circ} \mathrm{C}$. The value increased to $12 \%(8-15)$ if follicular fluid was added. The results indicate that if insemination with frozen-thawed spermatozoa is carried out 10-12 hours prior to ovulation, there is almost no chance of fertilization though conditions in the oviducts decidedly are more pertinent than in our experiments with follicular fluid. Our findings differ from those by Pursel et al.(1975), who reported that deep-frozen spermatozoa maintained their fertility for at least 20 hours after thawing. An explanation for the different results might be the difference in composition of diluents and freezing techniques. In spite of the above-mentioned differences results are close to those of Polge et al. (1970), who counted $83.5 \%$ of fertile eggs after surgical administration of spermatozoa into oviducts, while merely $2.8 \%$ after administration into uterine horns of spermatozoa with a motility of $30 \%$. In the course of testing survival of spermatozoa without addition of follicular fluid, 16 gilts were inseminated and 7 of them $(43.75 \%$ ) became pregnant. This insemination rate indicates a short-time survival and consequently fertilizing ability of frozen-thawed boar spermatozoa. Conception is achieved only after insemination carried out shortly prior to ovulation.

\section{Vliv folikulární tekutiny na motilitu spermií kance po rozmražení}

Ejakulát kance byl zmrazován $\mathrm{v}$ objemu $0,1 \mathrm{ml}, 2 \mathrm{ml}, 5 \mathrm{ml}$ ve formě pelet na suchém ledu $\mathrm{CO}_{2}$ a v objemu $2 \mathrm{ml}, 5 \mathrm{ml}$ a $10 \mathrm{ml}$ ve formě válečků $\mathrm{v}$ parách tekutého dusíku. Po 1 až 6 měsíčním uchovávání byl hodnocen pohyb spermií po rozmražení a jejich držení při teplotě $38,5^{\circ} \mathrm{C}$ i po přidání folikulární tekutiny $z$ vaječníků prasnic. Bylo zjištěno statisticky významné snížení pohyblivosti spermií ve vzorcích mražených $\mathrm{v}$ objemu $10 \mathrm{ml}$, oproti vzorkům mraženým v objemu $0,1 \mathrm{ml}$. Po rozmražení byl zjištován přímočarý pohyb asi u $30 \%$ spermií. $\mathrm{Za} 6$ hodin klesl pohyb tak, že byl zjištován v prủměru jen u $7 \%$ spermii $(2-10)$ a ve vzorcích $\mathrm{s}$ folikulární tekutinou byl zjištován $\mathrm{v}$ průměru $\mathrm{u} 12 \%$ spermií $(9-15 \%)$. U nemraženého ejakulátu, drženého za stejných podmínek, byla zjištována pohyblivost u $48 \%$ spermií. Z 16 prasniček inseminovaných zmrazeným semenem bez folikulárni tekutiny zabřezlo 7, tj. 43,75 \%. Relativně nízká přežitelnost spermií kance po rozmražení mưže být přičinou slabších výsledků v zabřeznutí prasnic. 


\section{Влияние фоликулярной жидкости на подвижность сперм боровов после разморожения}

Проводилось размораживание эякулята борова в объеме 0,1 мл, 2 мл, 5 мл формой дражирования на сухом льде $\mathrm{CO} 2$ и в объеме 2 мл, 5 мл и 10 мл в форме валиков в паре жидкого азота. После хранения в течение 1-6 месяцев проводилась оценка движения сперм после разморожения и их устойчивости при температуре $38,5^{\circ} \mathrm{C}$ и после добавления фоликулярной жидкости яичников свиноматок. Было выявлено статистически значимое понижение подвижности сперм в образцах, замораживаемых в объеме 10 мл, по сравнению с образцами, самораживаемыми в обьеме 0,1 мл. После размороженил было выявлено прямолинейное движение около $30 \%$ сперм. Спустя 6 часов понизилось движение настолько, что оно имело место лишь у $7 \%$ сперм $(2-10)$ и в пробах с фоликулярной жидкостью было движение установлено лишь у 12 \% сперм (9-15\%). У хранимого в одинаковых условиях незамороженного эякулята была установлена подвижность в случае $48 \%$ сперм. Из 16 свиноматок, оплодотворенных замороженными спермами, стало беременными 7 , т. е. 43,75 \%. Относительная низкая живучесть сперм борова после разморожения может быть причиной не особо удовлетворительных результатов забеременения свиноматок.

\section{References}

FOLEY, C. W. - WILLIAMS, W. L.: Effect of bicarbonate and oviduct fluid on respiration of spermatozoa. Proc. Soc. Exp. Biol. Med., 126, 1967: 634-637.

GROTJAN, H. E. - DAY, B. N. - MAYER, D. T.: Porcine spermatozoan respiration in the presence of porcine follicular fluid. J. Amin. Sci., 38, 1974: 1235-1238.

GROTJAN, H. E. - DAY, B. N. - MAYER, D. T.: Porcine spermatozoan respiration and motility in the presence of bovine follicular fluid. J. Anim. Sci., 40, 1975: 96-98.

HAMMER, C. E. - WILLIAMS, W. L.: Identification of sperm stimulating factor of rabbit oviduct fluid. Proc. Soc. Exp. Biol. Med., 117, 1964: 240-243.

KONONOV, V. P.: Personal communication.

POLGE, C. - SALOMON, S. - WILMUT, I.: Fertilizing capacity of frozen boar semen following surgical insemination. Vet. Rec., 87, 1970: 424-428.

PURSEL, V. G. - JOHNSON, L. A.: Effect of time of insemination on fertilizing capacity of frozen boar spermatozoa. J. Anim. Sci., 41, 1975: 375.

YANAGIMACHI, R.: In vitro acrosome reaction and capacitation of golden hamster spermatozoa by bovine follicular fluid and its fractions. J. Exp. Zool., 170, 1969: 269-272. 